\title{
The Effect of Weather Factors on the Population Density of Oxycarenus spp. (Hemiptera: Lygaidae) on Roselle and Kenaf
}

\author{
${ }^{1 *}$ O. T. Alamu, ${ }^{1}$ A. O. Amao, ${ }^{20}$ O. M. Dahunsi, and ${ }^{1}$ J. A. Ete \\ ${ }^{1}$ Forestry Research Institute of Nigeria, Jericho Hill, Ibadan, Nigeria. \\ 2Savanna Forestry Research Station, Samaru, Zaria, Nigeria \\ [Corresponding Author e mail: tomniyialamu@yahoo.com; alamu.ot@frin.gov.ng]
}

\section{ABSTRACT}

Roselle, Hibiscus sabdariffa and Kenaf, Hibiscus cannabinus are two important fibre crops in most parts of Africa. Insect pests are one of the major constraints in the production of these crops. The cotton seed bug Oxycarenus spp. attacks Roselle and Kenaf during the seed formation stage and cause reduction in seed viability. This study examined the effect of weather factors namely, relative humidity, temperature, sunshine and soil evaporation on the population density of Oxycarenus spp. on Roselle and Kenaf during the planting seasons 2012 and 2013. The treatments consisted of two types of Roselle (Green-calyxed and Redcalyxed) and Kenaf. The experiment was laid out in the field using Randomized Complete Block Design and the treatments were replicated four times. The results showed that the population of Oxycarenus spp. was significantly $(p<0.05)$ higher on green-calyxed $H$. sabdariffa and red-calyxed $H$. sabdariffa than on Kenaf in 2012 and 2013. The differences in the density of the bug per fruit on green-calyxed $H$. sabdariffa and redcalyxed $H$. sabdariffa were significant in the two planting seasons. Relative humidity in the morning and maximum temperature correlated positively and negatively, respectively with the density of Oxycarenus spp. during the two planting seasons. Sunshine hours per day correlated positively, while soil temperature and soil evaporation had a negative correlation with the bug density. This information on the seasonal variation in the bug density and its relationship with weather factors could be used in pest forecasting for these fibre crops which is an important tool in formulating a successful pest management programme.

Keywords: Malvaceae, Fibre crops, weather factors, Oxycarenus spp., pest management, planting seasons, pest density.

\section{INTRODUCTION}

Roselle (Hibiscus sabdariffa L.) and Kenaf (Hibiscus cannabinus L.) belong to the family Malvaceae. In Nigeria, two botanical varieties (red-calyxed and green-calyxed) of $H$. sabdariffa are recognized. The calyx of the red variety is commonly used for the preparation of "Sobo" drink while the calyx of the green variety is used to cook soup, stew and sauces. The calyx of green roselle is very rich in vitamin $C$ and riboflavin with some major mineral present (Babalola, 2000). Kenaf (Hibiscus cannabinus L.) is commonly cultivated for both food and fiber in West Africa. Fiber in both the retted and raw forms is used in the manufacturing of cordage and newsprint. The increases in global demand for paper and paperboard materials have increased the importance of Kenaf as a wood substitute (Adegbite et al., 2005). It is estimated that Kenaf is 3 to 5 times more productive per unit area of land than pulpwood trees and produces a pulp that is equal or superior to many woods (Theisen et al., 1978)

Insect pests infestation is one of the major factors militating against the cultivation of crops from the family Malvaceae. The cotton seed bug, Oxycarenus spp. (Hemiptera: Lygaeidae) is a pest of cotton and other members of the Malvaceae plant family, including kenaf, okra, and roselle. Oxycarenus spp. do not only feed on other plants in the order Malvales, especially in the family Malvaceae, but also in Tiliaceae and Sterculiaceae (Slater and Baranowski, 1994). This insect causes economic damage when it feeds on cotton seeds thus, reducing seed germination and oil quality. It is native to Africa, and has been reported to have been intercepted 
on materials from Africa, Asia, Europe, the Middle East, Central America, South America and the Caribbean (Halbert and Dobbs, 2010).

Weather factors like temperature, relative humidity and rainfall play a vital role in multiplication and distribution of insect pests (Zafar et al., 2013). The numbers of generations and seasonal abundance of insects, especially phytophagous ones in a year are influenced by temperature, host selection and host suitability. Rainfall directly and indirectly influences seasonal abundance of pest by affecting the abundance and suitability of host plants (Zafar et al., 2013). To develop any pest management programme for a specific agro- ecosystem, complete knowledge on abundance and distribution of pest in relation to weather factors is a basic requirement (Patel and Shekh, 2006). For effective pest management strategy, it is necessary to know the proper ecological requirement of a pest species.

In Nigeria, 0 . gossypinus (Distant) and 0 . hyalinipennis (Costa) are the most abundant species, and they co-exist on their host plants, cotton, okra, roselle and kenaf. The biology of $O$. gossypinus on Okra in Nigeria has been studied (Ewete and Osisanya, 1988), however, little is known on the population of the bug on kenaf and roselle. This work was therefore conducted to provide information on the relationship between weather factors and the seasonal abundance of Oxycarenus spp. on roselle and kenaf.

\section{MATERIALS AND METHODS}

Experimental Site (or field)

The research was conducted during the growing season in July to December, 2012 and repeated in July to December, 2013 at the experimental field of Savanna Forestry Research Station, Samaru, Zaria (Latitude $07^{\circ} 05^{\prime} \mathrm{N}$, Longitude $04^{\circ}$ $\left.50^{\prime} \mathrm{E}\right)$. The experimental site was situated in the Northern Guinea Savanna agro-ecology of Nigeria with frequent rain ranging between 165 and $250 \mathrm{~mm}$.

\section{Methodology}

The experiment was laid out in a Randomized Complete Block Design (RCBD) with three treatments made up of Hibiscus cannabinus and two varieties of Hibiscus sabdariffa (green calyxed and red calyxed) replicated four times. Each experimental plot was $4 \mathrm{~m}$ long and $3 \mathrm{~m}$ wide, with 6 rows of $50 \mathrm{~cm}$ apart and plant to plant distance of $30 \mathrm{~cm}$, giving a plot area of 12.0 $\mathrm{m}^{2}$. Each plot was separated with a distance of $1 \mathrm{~m}$. The experimental site was harrowed and ploughed using animal traction before marked out into plots. Two seeds were planted per hill (planting hole) and seedlings were thinned down to 1 stand per hill 2 weeks after germination. The plots were weeded three times at 15, 45 and 75 days after sowing.

Sampling for Oxycarenus spp. commenced 2 weeks after fruiting and continued weekly for 4 weeks. At each sampling time, ten fruits were randomly picked from each plot and put individually in a sampling bag. The fruits were carried to Entomology Research laboratory, Savanna Forestry Research Station, Samaru, Zaria where they were dissected to expose the bugs. The number of bugs per fruit consisting of the adults and the nymphs were counted and recorded.

Statistical analysis

The number of bugs per fruit was transformed using square root transformation $(x+0.5)^{1 / 2}$ before being analyzed using the Analysis of Variance (ANOVA). Significant means were separated using Tukey's Honestly Significant tests at $p \leq 0.05$. Weather factors for the two planting seasons were collected from the Meteorological Station of the Institute of Agricultural Research, Ahmadu Bello University, Zaria. Linear correlation analysis was carried out to determine the relationship between the weather factors and the population of Oxycarenus spp. 


\section{RESULTS AND DISCUSSION}

In 2012, the population of Oxycarenus spp. per fruit was significantly higher in green-calyxed $H$. sabdariffa $(4.09 \pm 1.51)$ than in red-calyxed $H$. sabdariffa (3.63 \pm 1.73$)$ and $H$. cannabinus $(1.19 \pm 0.50)$. With an average of $7.00 \pm 1.76$, the number of Oxycarenus spp. was significantly higher on red-calyxed $H$. sabdariffa than on the green-calyxed $H$. sabdariffa and $H$. cannabinus. In both planting seasons, the number of Oxycarenus spp. recorded on $H$. cannabinus was significantly lower than the number recorded on green-calyxed $H$. sabdariffa and red-calyxed $H$. sabdariffa (Table 1).

Table 1: Population of Oxycarenus spp per fruit $( \pm$ S.E) on three Hibiscus species during 2012 and 2013 growing seasons in Samaru

\begin{tabular}{lll}
\hline Crops & 2012 & 2013 \\
\hline $\begin{array}{l}\text { Hibiscus } \\
\text { cannabinus }\end{array}$ & $1.19 \pm 0.50^{\mathrm{c}}$ & $1.99 \pm 0.33^{\mathrm{c}}$ \\
$\begin{array}{l}\text { Green-calyxed } \\
\text { Hibiscus }\end{array}$ & $4.09 \pm 1.51^{\mathrm{a}}$ & $5.25 \pm 1.38^{\mathrm{b}}$ \\
$\begin{array}{l}\text { sabdariffa } \\
\text { Red-calyxed } \\
\text { Hibiscus } \\
\text { sabdariffa }\end{array}$ & $3.63 \pm 1.73^{\mathrm{b}}$ & $7.00 \pm 1.76^{\mathrm{a}}$ \\
\hline
\end{tabular}

Means with the same alphabet in the column are not significantly different from each other at $p \leq$ 0.05

The fruit of $H$. cannabinus are small and hairy while the fruits of the two varieties of $H$. sabdariffa are large and smooth. The possession of hairs on the fruits of $H$. cannabinus may prevent the attraction of the bugs contrary to the fruits of $H$. sabdariffa which are smooth. Secondly, the big fruit size with corresponding high number of seeds may also influence the density of Oxycarenus per fruit. The presence of large number of seeds in $H$. sabdariffa may enhance abundance of food for the multiplication of the bugs than in $\mathrm{H}$. cannabinus (Adu-Mensah and Kumar, 1977).
As presented in Figure 1, the number of bugs per fruit in 2012 increased in the three plants from 2 weeks after fruiting, peaked at 4 weeks after fruiting and declined thereafter. In 2013, the number bugs per fruit in each of the Hibiscus species increased from the second week after fruiting up to fifth week after fruiting (Figure 2). In the two planting seasons, density of Oxycarenus increased sharply from the third week after fruiting. These periods coincided with the seed maturity stage which favoured the development and multiplication of the nymphs and adults of Oxycarenus spp. During these periods, the fruits dehisce and the bugs have free access to the seeds.

The relationship between the weather factors and the density of the bug showed that relative humidity in the morning correlated negatively with the number of bugs in both planting seasons (Table 2). Maximum and minimum temperatures correlated positively with the bug population in the two planting seasons except in 2013 where minimum temperature correlated negatively with the bug density. This is an indication that humid weather does not favour the population build of Oxycarenus spp. on Kenaf and Roselle in the study area. Similar studies on Oxycarenus spp. reported relative humidity and temperature correlated negatively and positively, respectively with bug population (Patil et al., 1992; Chaudhari et al., 1999; Qayyoum et al., 2014). Insects are able to function faster and more efficiently at higher temperatures as warm climate positively influence their feeding, development and dispersal (Drake, 1994).

The number of sunshine hours per day also correlated positively with the bug density in 2012 and 2013. Soil temperature and evaporation had a negative correlation with the bug density during planting seasons. This explains that bug infestation could be high at low rate of soil evaporation. However, this may not be the case as Oxycarenus spp. are not soil-living (subterranean) pests. The variation in the density of cotton bug on Kenaf and Roselle between the 
two planting seasons and also the variation in the influence of some weather factors are indications that weather factors are critical in forecasting the population of this bug. Weather factors have been described to have direct impact on insect population dynamics by modulating the developmental rates, survival, fecundity, voltinism and dispersal (Karuppaiah and Sujayanad, 2012). This study thus demonstrates a seasonal population fluctuation of Oxycarenus spp. on Roselle and Kenaf in relation to weather factors.

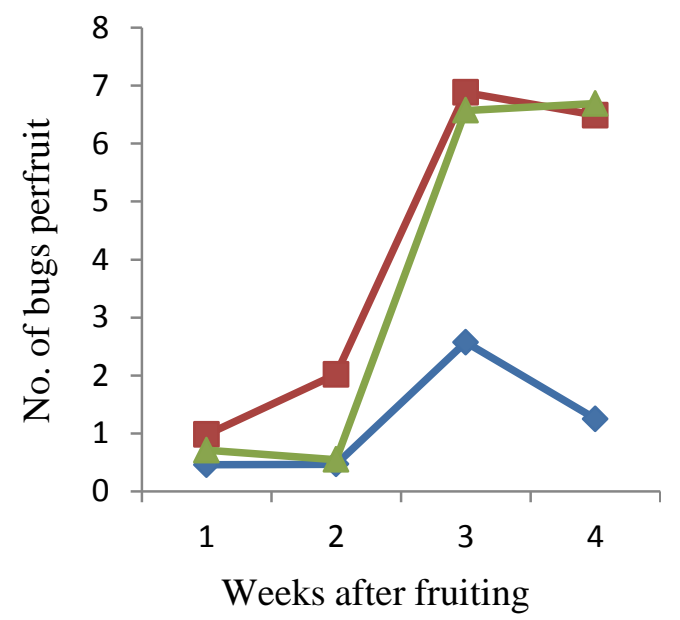

Figure 1: Population of Oxycarenus spp. on three Hibiscus species in Samaru during the 2012 growing season

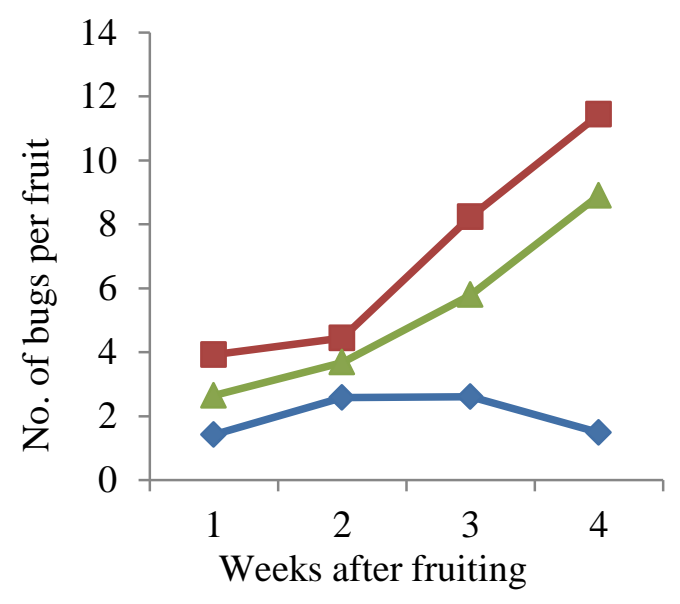

Figure 2: Population of Oxycarenus spp. on three Hibiscus species in Samaru during the 2013 growing season
Table 2: Linear correlation coefficients of the relationship between weather factors and the number of Oxycarenus spp. on three Hibiscus species in Samaru, during 2012 and 2013 cropping seasons

\begin{tabular}{|c|c|c|}
\hline $\begin{array}{l}\text { Weather } \\
\text { factors }\end{array}$ & $\begin{array}{l}\text { Linear } \\
\text { correlation } \\
\text { coefficient } \\
\text { (r) } 2012\end{array}$ & $\begin{array}{l}\text { Linear } \\
\text { correlation } \\
\text { coefficient (r) } \\
2013\end{array}$ \\
\hline $\begin{array}{l}\text { Relative } \\
\text { humidity (\%) } \\
\text { at } 10.00 \text { a.m. }\end{array}$ & -0.74 & -0.85 \\
\hline $\begin{array}{l}\text { Relative } \\
\text { humidity (\%) } \\
\text { at 4.00p.m. }\end{array}$ & 0.61 & -0.75 \\
\hline $\begin{array}{l}\text { Maximum } \\
\text { Temperature } \\
\left({ }^{\circ} \mathrm{C}\right)\end{array}$ & 0.089 & 0.14 \\
\hline $\begin{array}{l}\text { Minimum } \\
\text { Temperature } \\
\left({ }^{\circ} \mathrm{C}\right)\end{array}$ & 0.089 & -0.48 \\
\hline $\begin{array}{l}\text { Soil } \\
\text { temperature } \\
\left({ }^{\circ} \mathrm{C}\right) \text { at } \\
10.00 \text { a.m. }\end{array}$ & -0.29 & -0.75 \\
\hline $\begin{array}{l}\text { Soil } \\
\text { temperature } \\
\left({ }^{\circ} \mathrm{C}\right) \text { at } \\
\text { 4.00p.m. }\end{array}$ & -0.23 & -0.34 \\
\hline $\begin{array}{l}\text { Sunshine } \\
\text { (hours/per } \\
\text { day) }\end{array}$ & 0.43 & 0.82 \\
\hline $\begin{array}{l}\text { Open pan } \\
\text { evaporation } \\
\text { (mm) }\end{array}$ & -0.91 & -0.20 \\
\hline
\end{tabular}

\section{CONCLUSION}

Population dynamics of a pest is a key factor in planning effective management strategies. From this study, population of Oxycarenus spp. increased with the age of Roselle and Kenaf fruits. More damage to seeds is therefore expected to be inflicted on the seeds if they are left to over mature in the field. Timely harvest of the fruits is necessary to prevent further increase 
in the population Oxycarenus species on Kenaf and Roselle.

\section{REFERENCES}

Adegbite, A.A., Amusa, N.A., Agbaje, G.O., Akande, M.O. and Adetumbi, J.A. (2005). Expression of resistance to Meloidogyne incognita in Kenaf cultivars (Hibiscus cannibinus) under field conditions. Journal of Applied Sciences Research, 1(3): 321-324

Adu-Mensah, K. and Kumar, R. (1977). Ecology of Oxycarenus species (Heteroptera: Lygaeidae) in southern Ghana. Biological Journal of the Linnean Society, 9: 349377.

Babalola, S.O. (2000). Chemical analysis of roselle leaf (Hibiscus sabdariffa). In proceeding of 24th Annual Conference of NIFST, pp. 228-229.

Chaudhari, G.B., Bhsrpoda, T.M., Patel, J.J. and Patel, J.R. (1999). Effect of weather on activity of cotton pests in middle Gujrat. Journal of Agricultural Meteorology, 1(2): 137-142.

Drake, V.A (1994). The influence of weather and climate on agriculturally important insects: An Australia perspective. Australian Journal of Agricultural Research, 45: 487-509.

Ewete, F.K. and Osisanya, E.O. (1988). Studies on the biology of Oxycarenus gossypinus Distant (Heteroptera: L ygaeidae). East African Agricultural and Forestry Journal, 54(2): 79-83.

Halbert, S. E. and Dobbs, T. (2010). Cotton Seed Bug, Oxycarenus hyalinipennis (Costa): a serious pest of cotton that has become established in the Caribbean Basin. FDACS-Pest Alert DACS-P-01726. Florida Department of Agriculture and Consumer Services, http:/www.freshfromflorida.com/pi/pest_al erts/pdf/cotton-seedbug-alert pdf

Karuppaiah, V. and Sujayanad, G.K (2012). Impact of climate change on population dynamics of insect pests. World Journal of Agricultural Sciences, 8(3): 240-246.

Patel, H.R. and Shekh, A.M. (2006). Pest epidemics and role of meteorological services: An overview. Journal of Agrometeorology, 8: 104-113.

Patil, B.V., Nandihall, B.S., Hunger, P. and Somasekhar (1992). Influence of weather parameter on cotton bollworms and sucking pests. Karnatanka Journal of Agricultural Entomology, 5(4): 346- 350.

Qayyoum, M. A., Khan, B. S., Khan, N. A., Ghafar, A. and Bashir, M. H. (2014). Effect of abiotic factors on population dynamics of dusky cotton bug, Oxycarenus laetus Kirby, (Hemiptera: Lygaeidae) on cotton and its relationship with ginning factory areas. International Journal of Agriculture and Applied Science, 6(1): $22-25$.

Slater, J. A., and Baranowski, R. M. (1994). The occurrence of Oxycarenus hyalinipennis (Costa) (Hemiptera: Lygaeidae) in the West Indies and new Lygaeidae records for the Turks and Caicos Islands of Providenciales and North Caicos. Florida Entomology, 77: 495-497.

Theisen, A.A, Knox, E.G. and Mann, F.L. (1978). Feasibility of introducing food crops better adapted to environmental stress. Natl. Sci. Found., Div. Appl. Res. NSF/RA-780289. U.S. Govt. Print. Office, Washington, DC.

Zafar, K. Suhail, A., Arshad, M. and Jalal A, M. (2013). Impact of weather factors on population fluctuation of $\mathrm{H}$. armigera on Sunflower. Pakistan Journal of Nutrition, 12(1): 50-54. 